\title{
The Institutional Prerequisites for Post-Conflict Reconstruction
}

CHRISTOPHER J. COYNE

ccoyne@hsc.edu; www.ccoyne.com Hampden-Sydney College, Department of Economics, Box 863, Hampden-Sydney, VA 23943; Research Fellow, Mercatus Center, Arlington, VA 22201

Abstract. A successful post-conflict reconstruction is characterized by a self-sustaining liberal political, economic and social order that does not rely on external support. It is argued that the extent of reconstructed orders is constrained by their institutional prerequisites. These prerequisites-a shared ideology and ethic of individual and private property rights, a commitment to markets and the rule of law-are fundamental. Without these preconditions to serve as a foundation, reconstructed liberal orders will fail to be self-sustaining over time. It is argued that the viability of a shared ideology and ethic, and hence success, is directly dependent on the extent of horizontal ties in the post-conflict country. The main conclusion is that societies lacking adequate horizontal ties will require a high level of continual intervention and reconstruction efforts will have a lower probability of success.

Key Words: nation building, post-conflict reconstruction, social capital, social change, state building

JEL classification: $\quad \mathrm{O} 20, \mathrm{P} 11, \mathrm{P} 16, \mathrm{Z} 13$

\section{Introduction}

Writing over a century and a half ago, John Stuart Mill explored the reason behind "the great rapidity with which countries recover from a state of devastation... done by earthquakes, floods, hurricanes, and the ravages of war." Assuming that the disaster did not result in largescale depopulation, Mill concluded that individuals "with the same skill and knowledge which they had before. . . have nearly all the requisites for their former amount of production" (1848:82-3). Mill's insight is extremely relevant today, especially in the context of postconflict countries and reconstruction efforts within those countries.

The topic of post-conflict reconstruction is currently one of the most relevant policy issues in the world with major efforts underway in Afghanistan and Iraq. While the United States has past experience in post-conflict reconstruction, there is much we do not know. Applying Mill's analysis to these U.S.-led reconstruction efforts, why were Japan and Germany successfully reconstructed relatively quickly after war while Somalia and Haiti remain stuck in a trap of underdevelopment, non-cooperative behavior, and unhealthy institutions? Perhaps it is the case that a different set of knowledge and skills existed in prewar Japan and Germany as compared to Haiti and Somalia. This paper focuses on understanding the conditions or "requisites" necessary for success in the post-conflict situation.

Post-conflict reconstruction involves building or rebuilding both formal and informal institutions (Kumar 1997). Specifically, it involves the creation and restoration of physical infrastructure and facilities, minimal social services, and structural reform and transformation 
in the political, economic, social and security sectors. Reconstruction should not be confused with state building, nation building or peacekeeping. State building and nation building activities can be seen as a subset of reconstruction and involve transferring governance capabilities. Likewise, peacekeeping can be seen as a subset of reconstruction that involves stabilizing a war-torn society. Reconstruction is a broader notion that encompasses these, as well as other, activities.

Ultimate success in the reconstruction process is defined as the achievement of a selfsustaining liberal democratic state as well as liberal economic and social institutions. Selfsufficiency indicates that reconstructed orders do not rely on outside assistance in terms of monetary and/or military support. ${ }^{1}$ This definition is taken as the stated end of reconstruction efforts. ${ }^{2}$ The paper avoids normative questions and assumes that foreign forces will attempt to establish liberal orders in conflict-torn societies. ${ }^{3}$ Given the stated ends, this paper engages in a positive analysis to understand the conditions required for a successful reconstruction. The aim of the analysis is to understand if the means available to occupiers are suitable to achieve the desired ends. Public choice issues are assumed away in order to consider the "best" case where occupiers engage in activities which they believe will bring about the stated ends of reconstruction efforts.

While many economists have focused on specific economic policies in the reconstruction situation (Heller 1950, Keynes 1980, Mises 2000, Ohlin 1929, Foote et al. 2004), few have studied the reasons why these policies have succeeded or failed to generate the desired effects. This paper seeks to fill this gap. The aim is to contribute to our understanding of the ability of exogenous occupiers to achieve success in reconstructing post-conflict countries into liberal political, economic and social orders.

The main thesis is that the extent of reconstructed orders is constrained by their institutional prerequisites. ${ }^{4}$ These core prerequisites-a shared ideology and ethic of individual and private property rights, a commitment to markets and the rule of law-are fundamental. ${ }^{5}$ Without them to serve as a foundation, reconstructed liberal orders will fail to be self-sustaining over time. Stated differently, the institutional prerequisites serve as the "outer limits" of reconstructed orders, necessary for their very existence. The focus of this paper is on exploring the conditions under which these institutional prerequisites can effectively exist, how they develop and the related constraints on occupying forces.

To summarize the underlying argument, context matters for political, economic and social outcomes. Reconstruction is not just a matter of the occupying forces utilizing controllable variables to implement the right policies and undertake the right activities. ${ }^{6}$ Ultimate success requires the existence of institutional prerequisites that serve as a foundation allowing those policies and activities to "stick" and be effective once occupiers exit the conflict-torn country.

While the occupiers set the rules of the game that influence player strategies, these rules will only be binding if they are grounded in customary practice (Boettke 2001:254-7; North 2005:48-64). In the absence of voluntary recognition and acceptance by the populace, the political, economic and social rules of the game will fail to be self-sustaining. In contrast, if the institutional prerequisites align with reconstruction efforts, the process will be greatly eased. The populace will coordinate around the reconstruction efforts and they will be selfsustaining and self-extending over time. There will be no need for continual interventions for the maintenance of reconstructed orders. 


\section{The Outer Limits of Reconstructed Orders}

In his study of the market process, Israel Kirzner discusses the limits of the market. According to Kirzner, the outer limits of the market are determined by the prior presence of "extramarket institutions, without which the idea of a market process must be a mere dream" (2000:77). Applying this insight to the reconstruction process, certain core institutional prerequisites must be in place prior to the implementation of reconstructed formal institutions in order for them to operate as desired. To use Kirzner's terminology, these institutional prerequisites serve as the outer limits of reconstructed orders. They are the boundaries beyond which reconstructed orders will fail to operate as desired.

The stated ends of post-conflict reconstruction efforts-a self-sustaining liberal central democratic state and liberal economic and social institutions-dictate the required prerequisites. Specifically, widespread acceptance of a liberal ideology and ethic is necessary in order for reconstructed orders to be self-sustaining. Only in the case of such a shared ideology and ethic can the end goals of reconstruction be achieved. In cases where the required ideology and ethic are lacking, attempts to construct a central state will either fail to be self-sustaining or require continual external enforcement. ${ }^{7}$

To provide an example of this last point, consider the case of Afghanistan in the period following the fall of the Taliban. Many of the rules and laws, which the Taliban had established and imposed via force, were not self-sustaining absent the threat of coercion. After the war, Afghan men lined up for haircuts; women purchased makeup and patronized newly opened beauty salons. Thriving markets in imported TVs, VCRs and homemade satellites quickly developed. The underlying ideology and ethic did not support the formal rules put in place by the Taliban and, as a result, they failed to "stick" in the absence of formal enforcement. In contrast to this situation, a self-sustaining order requires that the de jure political, social and economic orders align to a large extent with the de facto ideology and ethic.

Given that the aim of reconstruction is to construct liberal institutions, we must first understand the conditions necessary for the existence of a shared ethic and ideology. In other words, what conditions are required for the existence of an ethic that can support formally reconstructed institutions? Second, we must analyze how the nature of this ethic is shaped and influenced. Ultimately, occupiers want to ensure that the de facto ethic aligns with de jure institutions so that they sustain and operate as desired once occupiers exit the country.

Cowen and Coyne (2005) provide insight into the conditions required for a shared ethic. Their analysis considers the factors that influence the level of conflict or cooperation in a conflict-torn society. They conclude that the existence or absence of social capital is one of the major contributing factors. Social capital emphasizes the role of social networks, connections and relationships. More specifically, social capital can be defined as the existence of a certain set of informal values or norms that are shared among members of a group. These shared norms and values facilitate cooperation and coordination (Fukuyama 1999:16; Putnam 2000:18-20). One can see a connection between Hayek's focus on local knowledge of "time and place" and social capital which is characterized by contextually specific knowledge that allows individuals to interact and "get things done" (Ikeda 2002:231-2). ${ }^{8}$ 
It is important to emphasize that just as social capital can have positive effects for society, there is a potential downside as well (Portes and Landolt 1996). The "dark side" of social capital may include such things as the exclusion of outsiders or the pressure to conform to norms and values to remain part of a group. For instance, social capital can lead to cooperation and reciprocation within a group, but it also necessarily excludes outsiders. Similarly, it is possible to have shared social capital within specific groups but conflict between groups. As a final possibility, one could envision the formation of social capital that joins heterogeneous agents around norms and values that run counter to economic growth and progress.

Examples of this latter case include many tribal societies in Sub-Saharan Africa. These tribes are connected with and cooperate with neighboring tribes. However, these tribes also possess strong egalitarian norms that prevent any one member from accumulating wealth. An individual's accumulation of wealth is met with jealously and resentment and is seen as antisocial behavior because it attempts to break traditional communal networks. This resentment exists both within each tribe and also between neighboring tribes (Platteau 2000:196-200). These shared egalitarian norms facilitate cooperation but prevent economic progress. Along similar lines, one observes failed and weak states where terrorist organizations share strong norms and values that are not compatible with a liberal order.

What this indicates is that social capital around shared norms by heterogeneous members of a society is critical for a shared liberal ethic and ultimate success in reconstruction. Existing social capital serves as a constraint on the populace in sharing a common ideology and ethic. This is due to the fact that bridging ties can foster widespread "identities and reciprocity..." (Putnam and Feldstein 2002:23). A fractionalized country with many heterogeneous groups that are tightly connected internally but not interconnected across groups is less likely to share a common ideology and ethic. In contrast, a society characterized by social capital fostering loose ties is more likely to share a common ideology and ethic given that heterogeneous groups and individuals are connected.

Examples of this latter point would be "high trust" societies such as the United States, Japan and Germany (Fukuyama 1996:149-255). While individuals and groups in these societies differ on many margins, there is a shared ethic consisting of a minimal level of trust, honesty and respect that pervades most daily activities. This underlying ethic, which arises when a society shares a certain set of values, allows for the movement from personal to impersonal exchange. The widespread sharing of values requires a certain connectedness among individual members of the society.

The existence of social capital that fosters bridging ties does not guarantee a successful reconstruction. In other words, social capital can be seen as a necessary, but not sufficient, condition for the institutional prerequisites of post-conflict reconstruction. It is necessary because interconnectedness is needed to share the required ethic across a society. However, it is not sufficient because, as noted above in the example of Africa, it is possible for social capital to exist around perverse ends that oppose reconstruction efforts.

In the context of post-conflict reconstruction, existing social capital can be seen as an exogenous constraint on occupiers and reconstruction efforts that cannot easily be shifted. While it is true that social capital can shift over time, it is critical to remember that it is embedded in cultural and social structures and entails local knowledge that cannot be 
fully understood or collected. Indeed, a growing literature on institutional path dependence focuses on how the past experiences of a society connect to the present and future (see North 1990:92-104, 2005:51-2, 62). As a result, social capital is not something that can be centrally planned and crafted in the desired manner by occupiers.

At this point, there is a straightforward implication. Those countries characterized by social capital that fails to support interconnectedness across heterogeneous groups will be extremely difficult to successfully reconstruct by centrally constructing formal institutions. More specifically, we should expect that the reconstruction efforts in these countries would have a lower probability of success relative to those countries possessing ties allowing for shared norms and values. These countries will lack the conditions necessary to achieve a shared ethic to serve as a foundation for a liberal state. Force will be required to substitute where bonds of trust and reciprocity are lacking. Given the ultimate goal of self-sustainability, this is not a desirable situation.

\section{Shifting the Outer Limits of Reconstructed Orders}

The previous section considered the conditions necessary for the existence of certain institutional prerequisites. This section focuses on how the nature of the outer limits of reconstructed orders changes. This requires an understanding of the change agents who generate conformity around a new ideology and ethic in addition to creating new social connections and relationships. Section 3.1 puts forth a framework for understanding the process of change as well as the agents who drive this process. Section 3.2 links this framework to the prior discussion of social capital.

\subsection{Information Cascades and Change Agents}

The theory of information cascades offers a means of understanding the process through which changes in the outer limits of reconstructed orders take place. Information cascade theory provides a rational choice explanation of conformity or "herding." In the basic model, individuals make successive choices based on a combination of both private and public information. ${ }^{10} \mathrm{~A}$ cascade occurs because as an increasing number of individuals choose a certain course of action, the level of public information increases. For some individual along the sequence of choosers-individual $x$-the benefit from following accumulated public information outweighs the benefit of relying on his private information. In this case, individual $x$ ignores his private information and acts solely on the public information based on the choices of those who acted before him. Likewise, those remaining in the sequence $(x+1, x+2 \ldots)$ also act solely on the same public information that was available to individual $x$ (Bikhchandani et al. 1992; Hirshleifer 1995). ${ }^{11}$

The behavior described by the cascade model is rational given that obtaining information has a positive cost. We would expect individuals to continue to accumulate private information up to the point where it yields no additional benefit when compared to publicly available information. In this case, the individual ignores his private signal and follows the public signal conforming to the behavior of those who preceded him. 
Within the basic information cascade model, the outcome depends critically on early choices. Given this, in the context of post-conflict reconstruction, and social change generally, what matters most are the first-movers who start the cascade. A cascade around the "wrong" ideology and ethic will serve to limit the extent of reconstructed orders.

As a specific example of this case, consider the actions and the subsequent outcomes of the actions of Sheikh Muqtada al-Sadr, an anti-American Shiite cleric in Iraq. Al-Sadr led an uprising in the city of Najaf that resulted in weeks of fighting between occupying troops and insurgents who followed him. One could envision a similar situation in which a cascade that aligned with the aims of the reconstruction greatly eased the overall process.

Diffusion theory, which analyzes how an idea, innovation or product moves through a society, offers a means of understanding the first-movers who initially adopt an idea and start a cascade. ${ }^{12}$ Many of the studies employing diffusion theory have found that it only takes a small number of individuals, often referred to as "change agents," to adopt an idea, innovation or product before it is accepted by a large number of people. Change agents are focal individuals who have well-established reputations in their social networks and groups as first-movers. They are entrepreneurial in that they are alert to the benefits of adopting a new idea or activity and, in doing so, inform members of their social network to such new opportunities.

Change agents are not limited to one specific type of individual in a specific role or occupation. Private individuals, political leaders, various individuals in the media industry, religious and civic leaders are all examples of change agents. These individuals can be seen as the catalysts of change in the underlying social ethic. Change agents are the first movers who influence the norms and values within their social network and start a cascade. Their actions can also lead to new connections between individuals and groups which were previously unconnected. This can take place through the adoption of a new product or idea that connects individuals or through the expansion of the social network itself.

Change agents are viewed by others in their social network as having relatively superior information. As such, they will often be the first-movers because it is in the interest of others, who have less information, to wait to act. Assume that individual $x$ is a well-established change agent within a social network. In other words, it is common knowledge within the social network that individual $x$ is perceived to possess superior information as compared to anyone else. If individual $x$ chooses first among several courses of action, a cascade will start immediately. Others in his social network will adopt the same course of action as individual $x$ because it is believed that he has superior information.

Information cascades and change agents have numerous analogues in the postwar setting. Civic, religious or political leaders who support terrorism, looting or general insurgency can generate a cascade that has an extremely perverse impact on reconstruction efforts. Likewise, change agents that engage in peaceful, cooperative behavior can generate a cascade that will contribute positively to reconstruction efforts.

\subsection{Change Agents, Information Cascades and Social Capital}

One of the central claims of this paper is that success in reconstruction efforts requires the existence of social capital allowing for bridging ties across society. A connection can 
be drawn between this claim, change agents and the magnitude of information cascades. Specifically, the more connected a society is, the more likely it is that a major change agent will adopt a certain course of action that leads to a widespread information cascade. In other words, the greater the extent of social ties and connectedness, the greater the potential for large-scale information cascades around either good or perverse ends. A society that is interconnected is more likely to have a few major existing change agents that can create an informational cascade of a much larger magnitude as compared to a case where social groups are unconnected and dispersed. ${ }^{13}$ As will be discussed in more detail in the next section, the role of Emperor in the post-World War II reconstruction of Japan serves to illustrate this claim.

In the case of a society characterized by many unconnected and heterogeneous groups sharing no common change agent, it will be increasingly difficult for the populace as a whole to coordinate on a shared ideology and ethic. One example of this is the warlords in Afghanistan who create a general state of insecurity through their continual rivalry with each other. Any existing relationships between warlords are low trust as they "... watch each other closely to take advantage of vulnerability or broken promises" (Abdullaev 2004:179). In the absence of bridging ties between these groups, there is no opportunity for them to develop a shared identity and ethic in either direction.

In situations characterized by unconnected groups, information cascades exist, but the magnitude of those cascades will be limited by the extent of social networks. Further, the likelihood of those cascades being around shared conjectures is low because groups do not interact with others. While some cascades may form around ends that support reconstruction efforts, others may form around activities and ideas that oppose those efforts.

With dispersed change agents each exerting influence over their specific group, the cost of control on the part of occupiers will increase greatly. Occupying forces will have to monitor the actions of a large number of change agents dispersed throughout society to ensure that they are not undertaking activities opposing to reconstruction efforts. This is evident in Iraq where U.S. troops monitor sermons delivered at mosques throughout the country to check for messages opposing reconstruction efforts. In cases where the necessary social ties are lacking, occupiers need to consider whether they can realistically undertake activities that foster connections across unconnected groups and influence the underlying ethic in the desired manner.

\section{Alternative Courses of Action for Occupiers}

We now have an understanding of the institutional prerequisites necessary for reconstruction, the social conditions required for those preconditions and the process through which the underlying ethic is influenced. As discussed, information cascades can develop around ends that support reconstruction efforts, but it is also possible that cascades can form around perverse ends that oppose those efforts. Change agents, as first movers in information cascades, play a key role in determining the direction in which these cascades develop.

Here we consider several courses of action utilized by occupiers in past reconstruction efforts in response to the potential negative impact of change agents. The main question is, how effective can occupiers be in generating coordination around the right ethic and ideology 
which aligns with reconstructed liberal orders? Specific focus is placed on understanding the effectiveness of occupiers given the constraints placed on them by the existence or absence of social capital.

\subsection{Compensating Change Agents}

One potential course of action is for occupying forces to compensate change agents to engage in activities supporting reconstruction efforts. Compensation can occur in a number of ways. Subsidies supporting certain change agents or the mechanisms they use to communicate is one means of compensation. For instance, the occupying forces in postwar Germany and Japan heavily subsidized both the media and cinema industries because they were well-established means of disseminating information in the prewar period.

Another means of compensating change agents is to hire them as employees who participate in the reconstruction process. The example of the Neue Zeitung newspaper in postwar Germany illustrates this course of action. The U.S. created a paper for their zone and hired German journalists and editors to staff the paper. The staff, monitored by the occupying forces, had knowledge of the indigenous culture and the most effective way to communicate ideas and information to the populace. Another example is Fullujah, Iraq, where the U.S. financed military leaders and troops from Saddam Hussein's Republican Guard to battle insurgents. These military leaders had intricate knowledge of the area and were also respected by Hussein's former troops.

There are several potential issues related to compensating change agents that must be considered. The first involves monitoring the compensated change agents to ensure that they act appropriately. The concern is that these agents may fail to effectively assist in the reconstruction process and that the ideology and practices of the previous regime will remain part of the new, reconstructed order.

In past reconstruction efforts, this potential problem has been overcome by detailed background checks and purges of those deemed to be threats to the reconstruction efforts. However, in those countries lacking widespread social ties, there will be fewer change agents linked to many groups. Instead, one would expect many dispersed groups each with their own social network and change agents. As such, it will be relatively costly to identify the many dispersed change agents let alone monitor their activities.

For instance, consider countries characterized by "warlordism" such as Liberia or Sierra Leone. These warlords are dispersed throughout society and engage in tax evasion, illegal taxation, arms and drug smuggling and protection rackets. Continually monitoring and punishing these individuals is an extremely costly task. Further, generating widespread support for large-scale social change around liberal ends has proved to be elusive. Even if one or several warlords are willing to support change, there are many others who are not.

Yet another potential concern is that compensating change agents will undermine their role as catalysts of change. If a change agent's social network perceives that he is adopting a certain idea or activity because he is being compensated, his reputation and, ultimately, his focal position may be in jeopardy. In such cases, the actions of occupiers to compensate change agents may erode existing social capital between the change agent and his social network. 


\subsection{Censoring Change Agents}

Occupying forces have historically employed censorship in their reconstruction efforts to control the flow of information. Looking at the pre-World War II history of both Germany and Japan, one observes stringent government censorship laws over media outlets such as newspapers, films and radio. This continued in the postwar occupation of both countries, although in different forms. In each case, the U.S. imposed a series of censorship laws that applied to individuals participating in the industry as well as the content of the message conveyed. For instance, in Japan, the occupying forces issued a directive on the "freedom of speech and the press" soon after Japan's surrender. The directive stated that "there shall be an absolute minimum of restrictions on freedom of speech" as long as it adhered "to the truth" and did not disrupt "public tranquility" (Dower 1999:406-7). ${ }^{14}$ Based on these historical events, it may seem tempting to believe that consensus can be engineered via censorship standards. However, this is far from the case.

Caution must be used in censoring information in postwar situations for a number of reasons. With increasing advances in technological capabilities available at decreasing costs, it is now possible to receive news and information from around the world. For instance, a growing number of Iraqi citizens have access to satellite television and the Internet. ${ }^{15} \mathrm{Like}-$ wise, some Afghan citizens have purchased homemade satellite dishes, constructed from flattened paint cans, and are able to receive hundreds of channels from around the world. ${ }^{16}$ As information capabilities continue to progress and the costs of obtaining information continue to fall, it will become increasingly difficult to control content. Moreover, if the populace is able to receive external information in addition to that provided by the occupying forces, attempts by the occupying forces to control content will potentially discredit their efforts. If this does occur, there is a real threat that censorship can be counterproductive.

Excessive censorship may also prevent the occupied country from developing a social and political order that can handle dissent. A self-sustaining liberal democratic social and political order must ultimately be robust enough to handle differing opinions and views. Censoring content to prohibit dissenting views can be counterproductive to this end goal as it may potentially prohibit the development of public discourse on political, economic and social issues.

Yet another concern is that censoring content may potentially lead to public backlash. For instance, in Iraq the U.S. banned the newspaper sponsored by the previously mentioned Sheikh Muqtada al-Sadr. Al-Sadr can himself be seen as a change agent who established a social network of unemployed youths to build the newspaper and also establish his own militia. The occupying forces accused the newspaper of creating unrest and inciting violence against occupation troops. Within hours of the paper's closing, hundreds of protestors gathered outside its main office. This illustrates the potential for backlash against censorship. Indeed, al-Sadr and his follows have engaged in violent resistance to the occupying forces in the city of Najaf leading to hundreds of deaths.

In addition to the issues raised above, the extent of social capital and development of the war-torn country will constrain the ability of occupiers to effectively engage in censorship. Both Japan and Germany were relatively developed both economically and in terms of information dissemination channels - media, cinema, etc. These mediums were centralized 
industries with a widespread reach. This will generally not be the case in lesser-developed countries. Moreover, countries characterized by low levels of bridging ties will consist of dispersed groups, each with their own sources of information. Controlling these dispersed sources of information will be an arduous endeavor that can be sustained only at a great cost.

\subsection{Manufacturing Change Agents}

Yet another course of action is for the occupying forces to attempt to create new change agents to influence the indigenous norms, values and ethic. Occupiers face two constraints when considering this course of action. The first is a lack of local knowledge required to establish effective change agents. Recall that change agents have an established reputation embedded within their social network. The occupiers lack the local knowledge necessary to ensure that the target populace will accept the change agent in this role.

The second, and related issue is the constraint of post-conflict social capital. As discussed above, a society characterized by an absence of widespread social ties will have many dispersed change agents that are able to influence their own social network. Attempting to create change agents for these dispersed networks will be extremely difficult and costly. Attempting to establish a central change agent will not have the desired effect since such societies lack the necessary connectedness.

In the case of Japan, the United States realized the importance of existing change agents and the difficulties associated with creating new ones. Perhaps the best example of this is Emperor Hirohito. Initially, there was intense debate regarding the role of the emperor in the reconstruction process. In fact, many Americans demanded that the Emperor be punished for what they considered to be war crimes. ${ }^{17}$ However, it was ultimately decided that the Emperor would play an active role in implementing the directives of the occupying forces (Dower 1999:212-3). This was done because the occupying forces were not sure how the Japanese populace would respond to MacArthur and the occupying troops. The Emperor was a well-respected change agent among the Japanese populace and the occupying forces wanted to utilize his established position to maintain social cohesion and ease the process of reconstruction. It is not clear that occupying forces have the knowledge necessary to create change agents who are as effective as indigenously generated and established agents.

\subsection{Implications for Reconstruction Efforts}

Given the above, the best course of action for occupiers is not the central imposition of institutions but rather the identification and provision of mechanisms through which sustainable change can come about. Existing social capital and social networks are readily apparent examples of these mechanisms. In societies with pre-existing social capital and networks, indigenous mechanisms will be relatively plentiful when compared to countries lacking social ties and networks.

As discussed earlier, the existence of social capital in the immediate post-conflict period is a constraint on occupiers. Occupiers can attempt to create conditions that allow for the emergence of new social capital. The difficulty with this strategy is the uncertainty regarding 
the amount of time required for the formation of the bonds necessary to support an extended liberal order. It is unclear that the "political will" necessary for prolonged occupations exists (see Marten 2004).

An additional concern is that government interventions aiming to create social capital can potentially have the opposite effect and erode or destroy existing ties (see Ostrom 2000:180-2). ${ }^{18}$ Indeed, it may be the case that external occupation can lead to a worse outcome than what emerges in the absence of a central government. Such is the case in Somalia as illustrated by Nenova and Harford's (2004) discussion of the current state of the country.

Most are familiar with the Hippocratic Oath and, more specifically, the dictum, "First, do no harm." As a general rule, this should be the principle that guides the international community both when considering occupying a conflict-torn country and also once an occupation has occurred. While policy choices made by occupiers clearly influence the outcomes of reconstruction efforts, there are a great number of uncontrollable factors that contribute to the ultimate outcome (see Bellin 2004-2005). There is not only the potential that occupiers will fail in their efforts to centrally impose liberal democracy. There is also the potential that they can do more harm than good (Coyne 2005). Given this possibility, in many cases refraining from intervention may be the preferable strategy.

\section{Determining the Prospects of Success}

Given the insights of this paper, one key issue is the ability of policymakers to determine the prospects for success prior to undertaking reconstruction efforts. Unfortunately, there are no simple means of predicting success. As Chamlee-Wright (2005) indicates, analyzing social capital from an Austrian perspective indicates that it cannot be aggregated and measured as a homogeneous mass. Given this, the best that one can hope to do is to understand the historical experiences of a conflict-torn country. The aim is to attempt to understand the extent of cooperative ties of individuals outside the group in power (Payne 2005:570).

One method of determining the existence or absence of bridging ties in a society is to study its political, economic and social history. A country characterized by low trust, civil war, ethnic tensions and a lack of experience with liberal orders will have a lower probability of success in reconstruction efforts. Understanding the historical experiences of a country is important because as Hayek notes,

Most. . countries have never preserved a constitution long enough to make it become a deeply entrenched tradition; and in many of them there is also lacking the traditions and beliefs which in more fortunate countries have made constitutions work which did not explicitly state all that they presupposed, or which did not even exist in written form (1979:107-8).

Consider, for instance, several of the U.S.-led post World War II reconstruction efforts. At least three of those countries-Somalia, Bosnia and Afghanistan—had experienced civil 
war over the three decades prior to reconstruction efforts. Likewise, Kosovo and Haiti experienced violent political instability and insurgency. Iraq was unified by force under the Hussein regime, but is also characterized by fractionalization along ethnic, tribal, geographic and religious lines. Further, Iraq has a history of violent politics both in regime changes and between established regimes and organized groups that resist authority. In contrast, Germany and Japan are trustful societies that have a long history of loose associations and ties. In these countries an advanced exchange economy based on impersonal exchange existed prior to the postwar reconstruction efforts (Fukuyama 1996:161-193; 209-219; 231-243).

Measures of institutional quality in the pre-reconstruction period can also assist in historical analysis. More specifically, these measures provide one indication of the presence or absence of an environment conducive to the creation and maintenance of bridging ties. ${ }^{19}$ While there are a number of different measures of institutional quality, the one considered here is the Polity IV data set (Jaggers and Marshall 2003) ${ }^{20}$ This measure is useful for our purposes because it provides composite indicators of democracy and autocracy for most countries from the 1800s forward.

Institutionalized democracy, as defined by the authors, consists of three key elements: (1) the presence of institutions and procedures through which citizens can express their preferences, (2) the presence of institutionalized constraints on the executive, and (3) the guarantee of civil liberties for all citizens in both their daily lives and political participation (Polity IV Project, Dataset Users Manual: 13). The authors define autocracy "in terms of the presence of a distinctive set of political characteristics." Specifically, autocracies "suppress competitive political participation. Their chief executives are chosen in a regularized process of selection within the political elite, and once in office they exercise power with few institutional constraints" (Polity IV Project, Dataset Users Manual: 14-15). Both the "Democracy" and "Autocracy" categories are additive eleven-point scales (0-10). The authors compute a combined "polity score," by subtracting the Autocracy score from the Democracy score. The resulting scale ranges from +10 (strongly democratic) to -10 (strongly autocratic).

Utilizing this measure of institutional quality enhances historical analysis in several ways. First, it indicates whether a country has experience with institutionalized democracy. Second, a stable and durable liberal democracy indicates that the populace possessed a shared ethic around liberal institutions in the past. Finally, effective institutions create an environment conducive to the development and maintenance of weak ties. They allow individuals to overcome the problem of ethnic tensions and engage in political, economic and social relationships that they otherwise would have been unable to participate in. While a minimal ethic is required for the sustainability of liberal institutions, once in place those institutions can serve to reinforce existing bonds and facilitate the creation of new ties (Knack and Keefer 1997:1274-1286).

Consider first the polity scores of Japan and Germany, often considered the two cases of successful U.S.-led post-conflict reconstruction: 


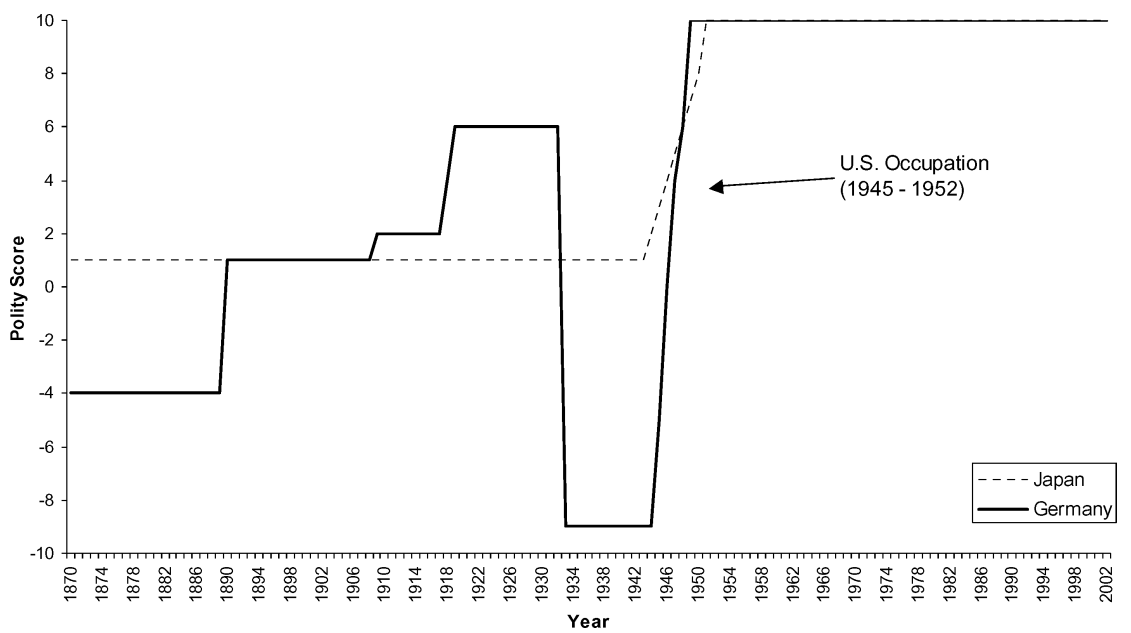

Figure 1. Japan and Germany Polity Scores: 1870-2002.

As Figure 1 indicates, Japan experienced a positive level of institutionalized democracy from at least 1870. Further, the political institutions were stable and durable which indicates that it provided a predictable environment in which weak ties could be developed and maintained. The polity score of Germany is more erratic as compared to Japan. However, Germany also experienced a period of positive democracy from 1890 until 1933, when Hitler rose to power. The quality of democratic institutions was especially strong under the Weimar Republic (1919-1933). In both Japan and Germany, citizens had experience with democratic institutions prior to the post-World War II reconstruction.

For comparative purposes, consider the historic polity score for Afghanistan and Iraq illustrated in Figure 2:

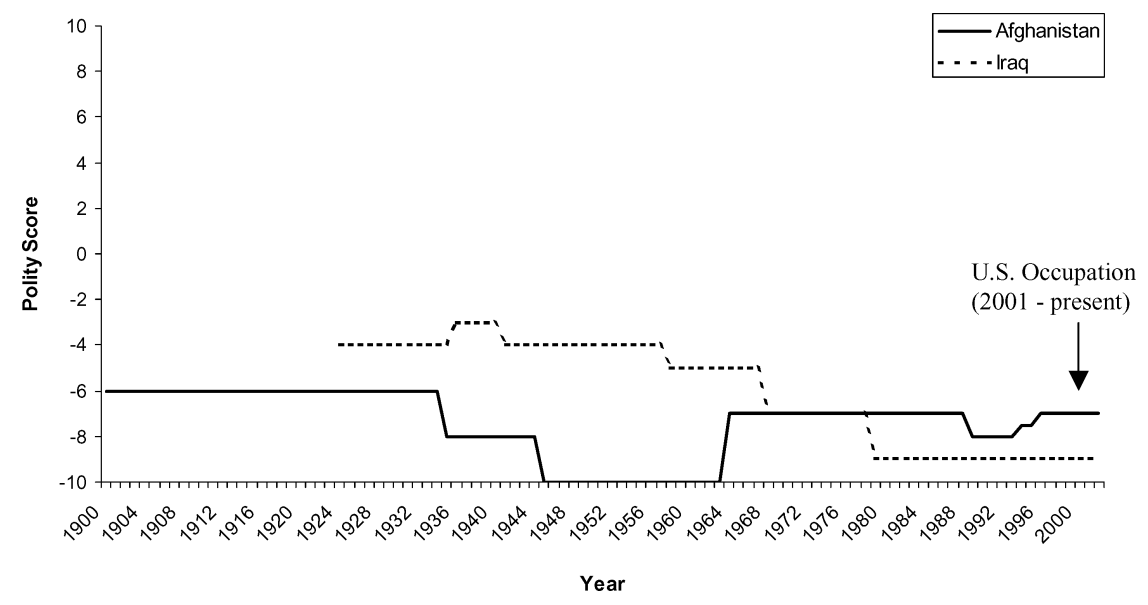

Figure 2. Afghanistan (1900-2002) and Iraq (1924-2002) Polity Scores. 
The highest polity score for Afghanistan is -6 in the period from 1900 through 1934. ${ }^{21}$ While political institutions were stable over this period, this score indicates that Afghanistan has not had experience with strong institutionalized democracy. Similarly, the institutional quality in Iraq is historically low. The Polity IV data for Iraq, beginning in 1924, highlights the fact that Iraq has never had experience with institutionalized democracy in its modern history. Further, since its establishment by the British in the 1920s, Iraq has experienced the rise and fall of successive brutal authoritarian regimes. Such an environment is not conducive to the creation and maintenance of bridging social capital. This would indicate that the reconstruction efforts in these countries are not comparable to efforts in Japan and Germany because the knowledge that developed in the pre-conflict period was drastically different. In Japan and Germany, a repressive minority stifled democratic traditions that had been long established while in Afghanistan and Iraq it is unclear that those traditions ever existed in the first place.

Assuming reconstruction efforts are to be undertaken, understanding the historical experiences and current situation of war-torn countries is critical to determining the prospects for success. Considered together, the approaches discussed here can contribute to that understanding. One would expect countries where the political and social environments have historically prevented the creation of bridging ties to be relatively more costly and difficult to successfully reconstruct. This is due to the fact that these countries are less likely to share norms supporting liberal institutions. Likewise, those countries with no historical experience with institutionalized democracy will be more costly to reconstruct relative to those that have had this experience. To return to Mill's aforementioned inquiry, those countries lacking the requisite skills and knowledge in the prewar period will be less likely to recover from the shock of war as compared to those countries possessing such skills and knowledge.

\section{Conclusion}

The main argument of this paper is that certain institutional prerequisites-a shared ideology and ethic of individual and private property rights, a commitment to markets and the rule of law-are critical to support successful reconstructed orders. Moreover, certain conditions-namely the existence of widespread social ties-are critical for the existence of these prerequisites. The underlying logic is that in absence of bridging social capital, the connections between individuals necessary to establish and support a shared ethic will be nonexistent.

While bridging ties are necessary, they are not sufficient because social capital can form around norms and values that run counter to reconstruction efforts. Occupying forces, through their policies toward change agents, can attempt to form consensus around the required ethic and ideology. However, it is far from certain that the desired outcome will be achieved for the reasons discussed in Section 4.

The main implication of this analysis is a humbling one. The institutions necessary for a liberal political, economic and social order cannot simply be transferred as desired. At a minimum, expectations as to what can realistically be achieved in reconstruction efforts should be substantially revised. It is clear that occupiers cannot externally orchestrate an 
extended liberal order. While policymakers and social scientists know what a successful reconstruction entails, they know much less about how to actually achieve that result. However noble the intentions, it is the hubris of those policymakers and government officials to assume away these issues and believe that liberal institutions can be transferred and engineered as desired.

\section{Acknowledgments}

I would like to thank Peter Boettke, Emily Chamlee-Wright, Tyler Cowen, Jack Goldstone Peter Leeson, David Levy, Frederic Sautet, Bob Subrick, Richard Wagner and participants in the Colloquium on Market Institutions \& Economic Processes, New York University and 2004 Southern Economic Association meetings, New Orleans for helpful comments. Financial assistance from the Earhart Foundation and Mercatus Center is acknowledged. The usual caveat applies.

\section{Notes}

1. The World Bank first used the term "reconstruction" in 1995. See Robert Muscrat, "The World Bank's Role in Conflict Prevention and Post-Conflict Reconstruction" (prepared for the Task Force on Failed States, World Bank, Washington, D.C., November 27, 1995).

2. It should be noted that there is a debate regarding the relationship between democracy and economic growth. See for instance, De Haan (1996), Hall and Jones (1999), Knack and Keefer (1995), and Tavares and Wacziarg (2001). Although important, it is not the aim of this paper to contribute to this debate.

3. For writings on the normative aspects of reconstruction efforts, see Damrosch (1993), Heiberg (1994), Hoffmann (1996) and Lugo (1996).

4. Institutions are the formal and informal rules that govern human behavior. The focus of this paper is on the informal norms, values and traditions that serve as the foundation for the formal constructed and reconstructed institutions.

5. Among others, Hume (1739), Hayek (1960, 1979), Smith (1776), and Tocqueville (1835, 1840) have discussed the prerequisites necessary for liberal political, economic and social orders. For these authors, liberal orders can only be sustained by supporting norms and social cooperation that emerge through a "bottom-up" process. Others have written on the prerequisites for democracy as well. Cohen (1971) concludes that democracy requires members of the populace to possess nine psychological traits including tolerance and flexibility. Corry and Abraham (1958:29-35) contend that democracy is grounded in seven fundamental beliefs. Likewise, De Grazia (1952:546-7) cites seven conditions necessary for democracy. Payne (2005) disagrees with these writers and contends that the minimum requirement for democracy is "a restraint in the use of violence in political affairs" (564). The prerequisites discussed here are not at odds with an absence of violence for political purposes. Indeed, a shared ethic grounded in a respect for individual and property rights as well as the rule of law precludes violence in political affairs.

6. One can differentiate between controllable and uncontrollable constraints on occupiers. Controllable variables would include such things as troop levels and financial resources that occupiers can vary as they wish. In contrast, culture would be an example of an uncontrollable constraint that occupiers cannot easily manipulate and vary as they so chose.

7. It is possible for a society to possess order and widespread cooperation in the absence of a central state. Somalia is one readily apparent example of this. In the complete absence of a central state, private individuals have developed mechanisms of governance to facilitate interaction (see Nenova and Harford 2004). The main point is that the social conditions in Somalia are not conducive to attempts by foreign occupiers to construct a central government which is the desired end of reconstruction efforts. Indeed, efforts to do so have increased conflict instead of facilitating cooperation (Menkhaus 2004:18). 
8. Baetjer (2000) discusses capital goods as embodying local knowledge and capital development as a social process. His analysis can be extended to the notion of social capital (see Chamlee-Wright 2005).

9. Bikhchandani et al. (1992) define an informational cascade as a situation in which "it is optimal for an individual, having observed the actions of others ahead of him, to follow the behavior of the preceding individual without regard to his own information" (992).

10. Public information refers to prior acts that are known to all.

11. This assumes that the costs, benefits and private information are the same for all individual choosers. Lohmann (1994) extends the basic cascade model to allow for differing costs and benefits to different individuals who choose in the sequence. In such a setting, a cascade may be rejected by those who choose later and who receive a smaller benefit from adopting what those who chose previously.

12. Perhaps the most well known study in this area is Ryan and Gross' study of the diffusion of hybrid corn in Iowa (1943). Other notable diffusion studies include Hagerstrand's study of the diffusion of TB tests in Sweden (1967) and Coleman et al's study of the diffusion of tetracycline among midwestern doctors (1966).

13. Change agents at the local and national level are not necessarily mutually exclusive. It is possible for certain change agents to influence behavior at a national level and others to influence behavior at a more local level. For example, contrast the leader of a country with the leader of a household.

14. For a detailed account of censorship in Japan, see Dower (1999:405-440).

15. Satellite television was banned under the Hussein regime but it is now estimated that $80 \%$ of Iraqi households have purchased satellite dishes (http://www.educationnews.org/satellite-television-is-iraq.htm).

16. In January of 2003, Afghanistan's most senior judge, Fazl Hadi Shinwari, banned cable television in Kabul. While local cable providers were forced to shut down, citizens are still able to access satellite cable since the government cannot control providers outside of the country.

17. A Gallup poll conducted six weeks prior to the end of the war indicated that $70 \%$ of the American population was in favor of executing or harshly punishing the emperor (Dower 1999:299).

18. Ikeda (2004) undertakes such an analysis and considers how government intervention through urban planning distorts norms of trust. Leeson (2005) provides an analysis of how government attempts to create homogeneity resulted in fractionalization in colonial Africa.

19. This should not be read as simply saying that those countries that possess liberal institutions can be reconstructed along liberal lines. Instead the methods of analysis put forth in this section are meant to provide a means of considering the general environment of a country. Specifically, they are aimed at understanding whether the environment is more or less conducive, relative to other countries, to the formation and maintenance of the social capital necessary for the development of a shared ethic. Even illiberal countries will differ in their degree of repression when compared to other illiberal regimes.

20. Knack and Keefer (1997) utilize the World Values Survey, beginning in 1981, as an indicator of social capital and trust. Knack and Keefer (1995), Hall and Jones (1999) and Acemoglu, Johnson, and Robinson (2001) use the International Country Risk Guide (ICRG) as a measure of institutional quality. This data, collected over the 1980s and 1990s, is based primarily on surveys and includes subjective assessments of risk for international investors along several dimensions. These dimensions include law and order, bureaucratic quality, corruption, risk of expropriation by the government and risk of government contract repudiation. Yet another measure of institutional quality is the aggregated index of government effectiveness compiled by Kaufmann et al. (2003). Beginning in 1996, this measure aggregates many subjective assessments of institutional quality into indices of government effectiveness. Unfortunately, the data of these indicators fails to cover the necessary countries and historical time frame of reconstruction efforts for comparative purposes.

21. Although not included in this graph because of the lack of comparable data for Iraq, the polity score of -6 for Afghanistan can be traced back to 1800 .

\section{References}

Abdullaev, K. N. (2004) “Warlordism and Development in Afghanistan.” In: Montgomery, J. D. and Rondinelli, D.A (Eds.) Beyond Reconstruction in Afghanistan, pp. 169-187. New York: Palgrave Macmillan.

Acemoglu, D., Johnson, S., and Robinson, J. A. (2001) "The Colonial Origins of Comparative Development: An Empirical Investigation.” American Economic Review, 91(5): 1369-1401. 
Baetjer, H. (2000) "Capital as Embodied Knowledge: Some Implications for the Theory of Economic Growth." The Review of Austrian Economics, 13(2): 147-174.

Bellin, E. (2004-2005) "The Iraqi Intervention and Democracy in Comparative Historical Perspective." Political Science Quarterly, 119(4): 595-608.

Bikhchandani, S., Hirshleifer, D., and Welch, I. (1992) "A Theory of Fads, Fashion, Custom, and Cultural Change in Informational Cascades." Journal of Political Economy, 100(5): 992-1026.

Boettke, P. J. (2001) "Why Culture Matters: Economics, Politics and the Imprint of History." In: Boettke, P.J. (Ed.) Calculation and Coordination, pp. 248-265. New York: Routledge.

Chamlee-Wright, E. (2005) "The Structure of Social Capital: An Austrian Perspective on its Nature and Development." Working Paper.

Cohen, C. (1971) Democracy. Athens: University of Georgia Press.

Coleman, J. S., Katz, E., and Menzel, H. (1966) Medical Innovation: A Diffusion Study. New York: Bobbs Merrill. Corry, J. A. and Abraham, H. J. (1958) Elements of Democratic Government. New York: Oxford University Press.

Cowen, T. and Coyne, C.J. (2005) "Postwar Reconstruction: Some Insights from Public Choice and Institutional Economics." Constitutional Political Economy, 16: 31-48.

Coyne, C.J. (2005) "Reconstructing Weak and Failed States: Foreign Intervention and the Nirvana Fallacy." Working Paper.

Damrosch, L. F. (1993) Enforcing Restraint: Collective Intervention in Internal Conflicts. New York: Council on Foreign Relations.

De Grazia, A. (1952) The Elements of Political Science. New York: Alfred A. Knopf.

De Haan, J. (1996) "New Evidence on the relationship Between Democracy and Economic Growth." Public Choice, 86(1): 175-198.

Dower, J. W. (1999) Embracing Defeat: Japan in the Wake of World War II. New York: W.W. Norton \& Company.

Foote, W., Block, W., Crane, K., and Gray, S. (2004) "Economic Policy and Prospects for Iraq." Journal of Economic Perspectives, 18(3): 47-70.

Fukuyama, F. (1996) Trust. New York: Simon \& Schuster.

Fukuyama, F. (1999) The Great Disruption. New York: The Free Press.

Hagerstrand, T. (1967) Innovation Diffusion as a Spatial Process. Chicago: University of Chicago Press.

Hall, R. E. and Jones, C. I. (1999) "Why Do Some Countries Produce so Much More Output per Worker than Others?" Quarterly Journal of Economics, 114(1): 83-116.

Hayek, F.A. (1960) The Constitution of Liberty. Chicago: The University of Chicago Press.

Hayek, F.A.. (1979) Law, Legislation and Liberty, Volume 3: The Political Order of a Free People. Chicago: The University of Chicago Press.

Heiberg, M. (1994). Subduing Sovereignty: Sovereignty and the Right to Intervene. London: Printer Publishers.

Heller, W. W. (1950) "The Role of Fiscal-Monetary Policy in German Economic Recovery." The American Economic Review, 40(2): 531-547.

Hirshleifer, D. (1995) "The Blind Leading the Blind: Social Influence, Fads, and Information Cascades." In: Tommasi, M. and Ierulli, K. (Eds.) The New Economics of Human Behavior, pp. 188-215. Massachusetts: Cambridge University Press.

Hoffmann, S. (1996) The Ethics and Politics of Humanitarian Intervention. Indiana: University of Notre Dame Press

Hume, D. [1739] (2000). A Treatise of Human Nature. Oxford: Oxford University Press.

Ikeda, S. (2002) "The Role of 'Social Capital' in the Market Process." Journal des Economistes et des Etudes Humaines, 12(2/3): 229-240.

Ikeda, S. (2004) "Urban Interventionism and Local Knowledge." The Review of Austrian Economics, 17(2/3): 247-264.

Jaggers, K. and Marshall, M. G. (2003) "Polity IV Project" Center for International Development and Conflict Management, University of Maryland. Website: http://www.cidcm.umd.edu/inscr/polity/

Kaufmann, D., Kraay, A. and Mastruzzi, M. (2003) "Governance Matters III: Governance Indicators for 1996-2002.” World Bank Policy Research Working Paper 3106, available at: http://www.worldbank.org/wbi/ governance/pdf/govmatters3.pdf 
Keynes, J.M. (1980) The Collected Writings of John Maynard Keynes: Volume XXV: Activities 1940-44, Shaping the Post-War World: The Clearing Union, D. Moggridge, D. (Ed.), London, Macmillan for the Royal Economic Society.

Kirzner, I. (2000) The Driving Force of the Market. New York: Routledge.

Knack, S. and Keefer, P. (1995) "Institutions and Economic Performance: Cross-Country Tests Using Alternative Measures." Economics and Politics, 7(3): 207-227.

Knack, S. and Keefer, P. (1997) "Does Social Capital Have an Economic Pay Off? A Cross-Country Investigation.” Quarterly Journal of Economics, 112: 1251-1288

Kumar, K (Ed.). (1997) Rebuilding Societies After War. Colorado: Lynne Rienner Publishers.

Leeson, P.T. (2005) "Endogenizing Fractionalization." Journal of Institutional Economics, forthcoming.

Lohmann, S. (1994) "Rationality, Revolution and Revolt: The (Hap-) Hazards of Informational Cascades.” Working Paper: Department of Political Science, UCLA

Lugo, L. E. (1996) Sovereignty at the Crossroads? Morality and International Politics in the Post-Cold War Era. Maryland: Rowman and Littlefield.

Marten, K.Z. (2004) Enforcing the Peace: Learning from the Imperial Past. New York: Columbia University Press.

Menkhaus, K. (2004) Somalia: State Collapse and the Threat of Terrorism. International Institute for Strategic Studies.

Mill, J. S. (1848) Principles of Political Economy. New York: D. Appleton and Company.

Mises, L. von. (2000) The Selected Writings of Ludwig von Mises, Volume 3: The Political Economy of International Reform and Reconstruction, Ebeling, R. (Ed.), Indianapolis: Liberty Fund.

Nenova, T. and Harford, T. (2004) "Anarchy and Invention: How Does Somalia Cope without Government?" Public Policy for the Private Sector. The World Bank, November.

North, D.C. (1990) Institutions, Institutional Change and Economic Performance. Massachusetts: Cambridge University Press.

North, D.C. (2005) Understanding the Process of Economic Change. New Jersey: Princeton University Press.

Ohlin, B. (1929) "The Reparation Problem: A Discussion.” Economic Journal, 39: 172-183.

Ostrom, E. (2000) "Social Capital: A Fad or a Fundamental Concept." In: Dasgupta, P. and Serageldin, I. (Eds.) Social Capital: A Multifaceted Approach, pp. 172-214. Washington D.C.: The World Bank.

Payne, J.L. (2005) "The Prospects of Democracy in High-Violence Societies." The Independent Review, IX(4): $563-572$.

Platteau, J. P. (2000) Institutions, Social Norms, and Economic Development. New York: Routledge.

Portes, A. and Landolt, P. (1996) "Unsolved Mysteries. The Tocqueville File II: The Downside of Social Capital." The American Prospect, 7(26): 18-21.

Putnam, R. D. (2000) Bowling Alone. New York: Simon \& Schuster.

Putnam, R. D. and Feldstein, L.M. (2002) Better Together. New York: Simon \& Schuster.

Ryan, B. and Gross, N. C. (1943) “The Diffusion of Hybrid Seed Corn in Two Iowa Communities.” Rural Sociology, 8: $15-24$.

Smith, A. [1776] (1991) The Wealth of Nations. New York: Prometheus Books.

Tavares, J. and Wacziarg, R. (2001) “How democracy affects growth?” European Economic Review, 45: 13411378.

Tocqueville, A de. [1835,1840] (2001) Democracy in America. New York: Penguin Putnam Inc. 